\title{
An Assessment of Public-Private-Partnerships in Land Servicing and Housing Delivery: The Case Study of Gaborone, Botswana
}

\author{
Faustin T. Kalabamu, Paul K. Lyamuya \\ Department of Architecture and Planning, University of Botswana, Gaborone, Botswana \\ Email:kalabamu@mopipi.ub.bw
}

How to cite this paper: Kalabamu, F. T., \& Lyamuya, P. K. (2017). An Assessment of Public-Private-Partnerships in Land Servicing and Housing Delivery: The Case Study of Gaborone, Botswana. Current Urban Studies, 5, 502-519.

https://doi.org/10.4236/cus.2017.54029

Received: November 21, 2017

Accepted: December 26, 2017

Published: December 29, 2017

Copyright ( 92017 by authors and Scientific Research Publishing Inc. This work is licensed under the Creative Commons Attribution International License (CC BY 4.0).

http://creativecommons.org/licenses/by/4.0/

\begin{abstract}
Botswana, like most countries in the developing world, has been daunted by an ever increasing demand for serviced land and housing in all its towns and cities. The pressure on municipal and central governments to allocate adequate attention and finance to house urban populations, especially the poor has also been rising. As a result, some countries (including Botswana) have developed public-private partnerships seeking to reduce public investments and risks associated with land servicing and provision of housing to the poor. This paper is an attempt to assess the performance of public-private partnerships in land servicing and housing delivery in Botswana taking Gaborone Municipal area as a case study. Data and information presented in this paper are drawn from secondary sources and in-depth interviews with key informants in the private sector, Botswana Housing Corporation, Gaborone City Council and the former Ministry of Lands and Housing. It notes that, contrary to common practices, Botswana has been able to involve private sector firms in land servicing and delivery of projects without explicit contracts. It has instead split delivery processes into phases whereby the government undertakes initial stages and transfers land to private sector firms to complete the process including erection of houses for sale and/or renting. Although the strategy may have relieved land and housing pressure on state resources, it appears to have excluded vulnerable and low income groups that are often target beneficiaries of state sponsored housing programmes. The paper ends with recommendations on how public-private partnerships in Botswana may be improved to achieve better efficiency and inclusiveness.
\end{abstract}

\section{Keywords}

Public-Private Partnership, Land Servicing, Housing Delivery, Botswana, Gaborone 


\section{Introduction}

Although Public-Private Partnership (PPP) arrangements have traditionally been deployed to construct or manage public sector infrastructure facilities and services (e.g. water and energy supply, roads and telecommunication), of late several countries have adopted PPP arrangements in land servicing and real estate developments. Countries that adopted the PPP model in land servicing and development include the United States of America, Canada, Australia, United Kingdom, Russia, Bulgaria, India, Pakistan, Malaysia, Thailand, Tanzania, Nigeria, South Africa and Botswana (Payne, 1999; Abdul-Aziz \& Kassim, 2011; Scribner, 2011; Kasala \& Burra, 2016). Through PPP arrangements, central and local governments in these countries have been able to finance, construct, own, operate and deliver affordable housing to their people by sharing risks according to predetermined contractual provisions (UN Habitat, 2011). More importantly, the PPP approach has been hailed for enabling governments and municipal authorities to deliver low-income housing without using state subsidies to keep rents and/or prices low. This paper seeks to assess the performance of the PPP approach in Botswana with particular reference to land servicing and housing provision in the city of Gaborone.

The paper is divided into seven parts. This introduction is followed by a discussion on the definition, origin, forms and benefits of public-private partnerships in service delivery. The next part explores the nature, evolution and extent of the land question and urban housing problem in Botswana, while Section 4 briefly discusses the case study area and the sources of data/information for this paper. Section 5 presents the Case Study, while Sections 6 and 7 discuss the findings and make recommendations on the way forward.

\section{An Overview of Public-Private Partnership (PPP)}

As observed by Sengupta (2006), the concept of Public-Private Partnership (PPP) is an offshoot of the wider enabling approach whose primary objective is to empower communities and reduce public sector burden in providing basic goods and services. The PPP enables the public sector (as a client or consumer) and the private sector (as a service or facility supplier) to blend their special skills and to achieve an outcome that neither party could on its own (Akintoye, Beck, \& Hardcastle, 2003; Jones \& Pisa, 2000). Under the PPP approach, the private consortium wholly or partly finances a project and, in addition, carries out one or several aspects of project implementation including design, construction, maintenance or operation of the facility while the government contributes land or finance and retains the oversight role. This is in contrast to privatisation "where the delivery of the public service is fully transferred to the private sector with little or no government oversight" (UN Habitat, 2011). According Payne (1999), only projects and programs in which both public and private sector entities have financial commitments, exposure to risk and some benefits or rewards may be included in the PPP category. 
According to the Commission of the European Community (2005), PPPs can be initiated through three avenues namely competitive dialogue (for public contracts), community initiative (mostly for concessions) and private initiatives (mainly for non-national operators). The last avenue is the one that many organisations argue in support.

Public-Private Partnerships (PPPs) are becoming an increasingly important tool for delivering public services both with regard to infrastructure assets (bridges, roads) and more complex assets (prisons, hospitals, utilities). According to Hawkesworth (2011):

PPPs can be viewed in a broad way as covering most interactions between the private and public sectors and in a more narrow way focusing on particular sets of risk-sharing and financial relationships. PPP principles will aid decision makers facing the trade-offs between three demands inherent in a PPP project process. First, the public sector must be a prudent fiscal actor. It falls on the decision maker to ensure that the PPP is affordable, that it represents adequate value for money, and that any fiscal risks are limited. Second, the demands for investment from particular sectors such as transportation, health and education have to be assessed prudently against each other so that the projects that are pursued are those that yield the highest return on investment for society as a whole. Finally, decision makers must balance the risk taken by the private sector and those retained by the public sector. It also requires deciding what the appropriate price such a transfer should be.

A key argument for PPPs is that through harnessing the private sector's expertise in combining the design and operation of an asset, the service can be provided in a more efficient manner, i.e. providing more value for money compared to traditional forms of procurement and production.

PPP approaches take various forms depending on how the public and private sectors agree to share responsibilities, risks and rewards from a particular project (Akintoye, Beck, \& Hardcastle, 2003: p. 3-6; UN Habitat, 2011). The partnerships range from a simple collaboration whereby a private sector institution (e.g. bank or pension fund) funds a public sector project to more complex arrangements in which a private sector body designs, builds, maintains and operates a public facility under a long term agreement with the government. The basic PPP contract types include service contracts, management contracts, afterimage or lease contracts, build-operate-transfer (BOT), concessions and joint ventures (ADB, 2009). However, according to Kasala and Burra (2016) and UN Habitat (2011) three approaches, namely Build Operate and Transfer (BOT), Build Own and Operate (BOO) and Private Finance Initiative (PFI), appear to be the most popular and relevant to land servicing. Under the BOT, the private sector finances, builds and operates the facility for a fixed period of time after which the ownership reverts to the public while under BOO the private sector operates the facility or service in perpetuity. The PFI is similar to BOO except that the public sector "purchases the services from the private sector on a long-term agreement" 
(Kasala \& Burra, 2016).

As appropriately observed by several authors (e.g. Jones \& Pisa, 2000; Payne, 1999; UN Habitat, 2011), many countries in the developing world adopted the public private partnership approach when they realised that their governments were, on their own, unable to resolve the numerous urban problems which include provision of infrastructure services (water supply, roads, sanitation, electricity etc.) and, of particular interest to this paper, serviced land for housing low income earners. Before adapting the PPP approach, almost all countries relied on the provider approach whereby the government was the direct provider of serviced land and housing in all urban areas. The provider approach was constrained by inadequate financial resources, weak logistical and administrative capacities, and lack of adequate skills and technologies. According to Sengupta (2006), the attempt to shift the responsibility of housing provision to the market economy also proved ineffective in respect of low income housing. The PPP approach, on the other hand, "brings together the efficiency in production and technical and marketing expertise of the private sector with the accountability and righteousness of the public sector" which results in improved living conditions as well as increased quantity and quality of housing stock (Sengupta, 2006: p. 459).

Studies undertaken to assess the performance of the PPP approach in land servicing and housing delivery indicate that the approach has been generally successful (Payne, 1999). According to Kasala and Burra (2016: p. 13-14), adoption of the PPP approach in the delivery of serviced land in Tanzania has generated the following benefits:

1) Resource savings by local authorities. The saved resources are used for the delivery of other services.

2) Supply and acquisition of land for community facilities (schools, clinics, etc.) and infrastructure facilities (roads, open spaces, cemeteries, etc.) at no cost to the government. The cost is borne by land owners and the private sector.

3) Reduced land related conflicts and spread of unplanned settlements as old boundaries are abandoned and new ones introduced based on survey plans.

4) Enhanced tax base and revenue collection by local authorities.

5) Growing trust, professional synergies and collaboration between the private sector, land owners, local authorities and professional/technical cadres.

6) Building and strengthening community resilience and social capitalcommunities build capacity to commit personal and group resources to invest and share risks in expensive and long term projects.

Besides increasing the supply of serviced land and restraining the growth of squatter settlements, the PPP approach has been faulted for escalating the price of residential plots (Ahmed, 1999) or bias towards meeting the land demands for the rich (Adusumilli, 1999). The remainder of this paper explores the strengths and weaknesses of the PPP approach in Botswana and Gaborone Municipality in particular. 


\section{Botswana: National and Historical Context}

The Government of Botswana has since colonial days assumed the responsibility of acquiring, servicing, allocation and administration of land for urban development. While this responsibility lay with the Public Works Department (PWD) during the colonial period, it shifted to the Ministry of Local Government and Lands (later known as the Ministry of Local Government, Lands and Housing) after independence. The Town and Country Planning Act (TCPA) of 1977 (which was extensively amended in 2013) has been the principal legislation governing land servicing and delivery in settlements declared "planning areas". The Act provided for 1) orderly and progressive development of land in both urban and rural settlements; 2 ) the preservation and improvement of amenities; 3) granting of permission to develop land; and 4) for monitoring the use of land.

The bulk of the above named activities were placed on the Minister for Local Government and Lands. Section 3 of the Act required the Minister to “... secure consistency and continuity in the framing and execution of a comprehensive policy with respect to the use and development of all land in Botswana" while Section 4 empowered the Minister to declare any part of the country or settlement as a "planning area". Part III of the Act required the Minister to prepare and approve development plans consisting of a report of survey, maps and proposals indicating and defining sites for various land use activities (that is, roads, parks, residential, commercial, agriculture, mining etc.) for all settlements declared planning areas. Part IV gave the Minister responsibilities for approving or rejecting applications to develop land in planning areas.

\subsection{Administrative Arrangements}

Although the Minister responsible for land matters appears to have had an impossible task, in practice s/he was assisted by various state ministries, departments and agencies as noted by Kalabamu (2000) and Kalabamu and Morolong (2004). In addition, and in spite of being a unitary state, the Minister was assisted by several sub-national institutions such as District and Municipal Councils, Land Boards and Village Development Committees. Initially, the role of sub-national institutions in land use planning, servicing and administration was largely advisory and could readily be ignored or overlooked by the Minister. The 2013 Town and Country Planning Act has, however, transferred some the Minister's powers and responsibilities to District, Municipal and City Councils. Under Section 5 of the Town and Country Planning Act (2013), every council was appointed a planning authority for its planning area. In terms of the amended Town and Country Planning Act, the Minister is currently responsible for formulation of national policies, strategies and programmes in respect to the use and development of land; declaration of planning regions and areas; and approval of regional and local development plans.

The most critical challenge facing District, Municipal and City council in executing their new mandate of land servicing and delivery is inadequate financial 
resources. As observed by Mosha (2005), local authorities in Botswana are not autonomous and largely rely on Central Government for both recurrent and development budgets. The central government provides between $64 \%-84 \%$ of recurrent expenditure by urban councils and covers $100 \%$ of their development budgets. Indeed, almost all planning areas have thousands of planned, demarcated and, at times, allocated plots but which lack basic services-namely, roads, water, electricity, sewerage and storm water drainage networks-as they await funds from central government. Serowe Planning Area, for example, has 6184 residential plots covering 535 hectares which have been planned, surveyed and allocated but beneficiaries have been unable to developed them due to lack of basic services (Envirometrix, 2017).

\subsection{Rapid Urbanisation and Demand for Land}

Botswana has since attainment of independence in 1966 experienced unprecedented urbanisation in terms of both numbers and quality of life. The number of towns and cities increased from 3 to 7 between 1964 and 2011 while 25 villages become urbanised ${ }^{1}$ and declared planning areas. During the same period, the proportion of people living in urban areas (including cities, towns and urbanised villages) increased from $4 \%$ to $64 \%$ of the nation's total population. Urbanised villages accounted for $65 \%$ of the total urban population. Rapid urbanisation in Botswana has been attributed to rural-urban migration caused by widespread poverty in rural areas and relatively higher incomes in cities and towns (Silitshena, 1984); and high public investments and job creation opportunities in Gaborone and the mining centres such as Orapa, Jwaneng and Selibe-Phikwe (Colclough \& McCarthy, 1980). The third force that has been fuelling rural-urban migration is the country's unparalleled economic growth and prosperity. The exploitation of minerals (notably diamonds) has enabled the country's Gross Domestic Product (GDP) to grow at an average of 8.7 per cent per year in real terms during the 1966-2008 period (Government of Botswana, 2009a: p. 35). Mineral revenues have enabled the government to balance its recurrent budgets as well as undertake huge capital investments in education, health, transport, energy and water resources.

Rural-urban migration did inevitably lead to overwhelming demand for land, housing and other facilities in urban centres. According to Kalabamu and Morolong (2004: p. 70-76) the demand for land and housing was highest in Gaborone followed far behind by Francistown, Lobatse and Selibe-Phikwe which resulted in emergence of squatter settlements such as Old Naledi (Gaborone), Peleng (Lobatse) and Botshabelo (Selibe-Phikwe). Starting the mid-1980s, the demand for housing spilled into villages and settlements surrounding towns and cities which, in turn, resulted into rapid growth of illegal, unplanned and unserviced residential developments in peri-urban areas. The peri-urban land inva-

${ }^{1}$ In Botswana, a village or rural settlement is granted "urban" status when its population exceeds 5000 and $75 \%$ of its workforce is engaged in non-agricultural activities. 
sions later became the subject of a presidential commission of enquiry in 1990 (Government of Botswana, 1992).

\subsection{National Policy on Land Servicing}

Available literature (e.g. Ministry of Lands and Housing, 2014; Mpabanga, 2011) indicates that prospects of engaging the private sector in land servicing and housing delivery were first conceived in the early 1990s as part of the government's privatisation and diversification strategies. At that time the government had become wary of relying heavily on revenues from non-renewal mineral resources and, consequently, sought to diversity the country's industrial base and increase citizen ownership and participation in various sectors of economy (Government of Botswana, 2003: p. 61). Although "privatization" was a popular catchword in government programmes during the 1990s, privatisation as a national policy was only adopted in 2000. It has since been defined as "all measures and policies aimed at strengthening the role of the private sector in the economy" (Government of Botswana, 2009b: p. 1). Through the privatisation framework, the government sought to improve "efficiency in the delivery of public services by creating opportunities for greater private sector participation in the economy" (ibid.).

Public-Private-Partnership, as a project management and implementation tool within the privatisation framework, was introduced in 1994 through a presidential directive (CAB 9/1994). The directive sought to: 1) reduce government expenditure on servicing of state land; 2) attract large scale industrial and commercial developments through a fast system of state land acquisition; and 3) promote economic diversification and job creation. The directive targeted both local and foreign investors who would be invited to tender for specific land parcels as advertised from time to time.

According to Ministry of Lands and Housing (2014), the main thrust of the directive with regard to land servicing was to underscore government's commitment and confidence in the private sector. In addition, the government sought to leverage on private sector resources for land servicing. The specific objectives of the directive were:

To streamline relations between the government and the private sector;

1) To ensure that private sector involvement in land servicing was consistent with existing land policies;

2) To respond to market signals in the demand for serviced land by utilising private sector resources;

3) To take into account the problems of low income groups (Ministry of Lands and Housing, 2014: p. 4-5).

The directive was extremely general and lacking in terms of specific responsibilities to be assigned to the private sector, duration of implementation, contributions to be made by each partner and so on. In addition, it was not clear whether this was a privatisation or partnership initiative. 


\subsection{Strategy on Private Sector Participation in Land Servicing}

Adopted in 2014, the Strategy on Private Sector Participation in Land Servicing is a policy implementation framework which seeks to augment and address flaws identified in the 1994 national policy on land servicing. The objectives of the strategy are:

1) To promote private sector participation in land servicing in all land tenure systems;

2) To respond to market signals in the demand for serviced land by utilizing private sector resources;

3) To take into account the needs of low income groups; and

4) To increase access to land for sustainable socio-economic development. (Ministry of Lands and Housing, 2014: p. 6-7).

Unlike the 1994 policy which limited private participation to servicing of state land, the 2014 strategy extends their involvement to all land tenure systems ${ }^{2}$. In addition, the 2014 strategy spells out responsibilities to be undertaken by the public and private sectors as follows:

Government will:

1) Make land available through purchase of freehold or compensation of communal land rights holders;

2) Prepare structure plans, detailed layouts and carry out cadastral surveys;

3) Provide bulk or primary infrastructure services;

4) Sell partly service land to private sector;

5) Supervise, regulate and monitor land services by the private sector.

Private sector will:

1) Provide freehold land, if available and willing to do so;

2) Design and construct infrastructure service it;

3) Handover infrastructure services to government and its agencies for operation and maintenance;

4) Sell serviced plots or build houses for renting and/or selling;

5) Donate $5 \%$ of the serviced plots to the government for the development of low cost houses.

The 2014 strategy is, for intent and purpose, an expression of the reality on the ground as revealed in the Gaborone case study discussed below.

\section{Study Area and Methodology}

The study area, Gaborone, has been Botswana's capital city since 1966 when the country attained independence from British colonial government. During the colonial era, the country's administrative headquarters were located at Mafikeng in South Africa. Botswana, with a population of 2.0 million people in 2011, is a landlocked country: surrounded by South Africa on the south and southeast;

${ }^{2}$ Botswana has three land tenure categories: state land where land is owned and administered by the government; tribal land where land is communally owned but administered by respective land boards; and freehold land which is private property (Dickson, 1990; Kalabamu, 2000). 
Zimbabwe on the northeast; Zambia, Angola and Namibia on the north; and Namibia on the west. As noted earlier, Botswana has experienced rapid urban population growth due to rural-urban migration fuelled by several factors including widespread poverty and inadequate paid employment opportunities in rural areas. Gaborone was chosen for this study because it has been the main recipient of rural-urban population movements. In addition, Gaborone has experienced the highest demand for serviced land and housing. It has also been the epicentre of public-private partnership activities.

Data and information presented in this paper was drawn from 1) secondary sources (government publications, newspapers, previous studies, conference and journal articles); and 2) in-depth interviews with key informants in the private sector, Botswana Housing Corporation, Gaborone City Council and the former Ministry of Lands and Housing.

\section{Gaborone Case Study}

Gaborone was conceived, designed and built in the early 1960s. Then the government owned all the land on which the town was to be built. The government demarcated and built all infrastructure services (roads, water supply, electricity networks, drainage systems etc.) and public facilities (notably schools, hospitals and health clinics). It also built houses which it rented out to senior civil servants. The private sector produced a few high cost houses for business people and affluent individuals outside government employment (Kalabamu, 1993: p. 30). Then the government's attitude towards private sector involvement in real estate development was characterised by severe hostility (Molebatsi, 1990: p. 12). Government's lone efforts were, however, quickly overwhelmed by the town's rapid population growth and demand for residential accommodation which, in turn, led to the emergence and growth of a squatter settlement (called Naledi or star) on a piece of land owned by the state and reserved for industrial use. The state reacted to the emergence of squatter settlements by introducing the Botswana Housing Corporation (BHC) and self-help housing schemes popularly known as SHHA.

\subsection{Botswana Housing Corporation (BHC)}

Established in 1971 as a state owned company, the Botswana Housing Corporation (BHC) was given the task of: 1) building houses to meet the needs of both central and local governments; 2) assisting individuals to build houses for themselves; and 3) building houses for sale to the public. According to Letsholo (1990: p. 1), the BHC took over possession and management of government's housing stock and then concentrated its efforts on construction of rental houses for civil servants and state owned companies. Despite being given the mandate to service land, the BHC initially depended "entirely on the delivery of serviced land by the Government before it could build any houses" (Letsholo, 1990: p. 2). Since 1998 BHC has been allocated chunks of un-serviced land which it had to service be- 
fore constructing houses for sale or letting. Under this arrangement, a portion of the serviced plots is allocated to the BHC and the remainder retained by the central government. Roads and other infrastructure services built by the BHC are transferred to the local authority or respective state utility company for operation and maintenance. The price of plots allocated to the BHC is offset against the cost of servicing the whole area.

\subsection{Self-Help Housing Agency (SHHA)}

Self-Help Housing Agency (SHHA) schemes were launched in 1982 when it was realised that the BHC "could not meet the full range of housing needs of the urban population, in particular, it could not provide accommodation which was affordable by the lowest income groups without substantial subsidy, which the government could not afford" (Government of Botswana, 1983: p. 28). SHHA schemes were rolled out in two forms: squatter upgrading and sites-and-services.

Under the upgrading initiative, the government undertook cadastral surveys and issued land titles to property owners who had until then been classified as squatters. It also provided property owners with technical advices and financial loans to enable beneficiaries to improve the quality of their houses. Finally, the government provided infrastructure services including roads, sanitation, schools, clinics and street lights. The sites-and-service programme focused on the delivery of serviced land in virgin or unoccupied areas (Government of Botswana, 1983).

\subsection{Accelerated Land Servicing Program (ALSP)}

Despite the establishment of the Botswana Housing Corporation and the Self-Help Housing Agency in the early 1970s, the housing problem had, by the mid-1980s, worsened and proved almost unsurmountable (Kalabamu, 1993; Euroconsult, 1990; Clifton \& Roscoe, 1984). The supply of serviced land was considered to be the primary constraint in government's effort to solve the housing problem: all that was required were "reputable investors, and some form of liquidity guarantee to commercial banks when they lend long against their short term deposits" (Government of Botswana, 1987: p. 27). As a result of the foregoing observations, the government introduced the Accelerated Land Servicing Program (ALSP) in 1988. The ALSP sought to rapidly place a substantial amount of serviced land onto the market in Gaborone and other urban areas.

The ALSP initiative was implemented through some form of public private partnership. While the government provided financial capital, land and legal/administrative support, the design of the project was undertaken by SwedePlan and a Dutch consortium (Euroconsult BV) was contracted to adjudicate, advise and manage the programme. According to Kalabamu (1993), the programme was divided into sixteen (16) projects of which half (8) were located in Gaborone. Four (4) of the 8 projects were implemented by the Ministry of Local Government, Lands and Housing (MLGLH) while another 4 projects or neigh- 
bourhoods were assigned to the Botswana Housing Corporation (BHC) for implementation. Both the MLGLH and the BHC contracted out most of the work to private companies. Besides providing infrastructure services (roads, electricity, sewerage and drainage networks), the corporation built houses for renting and outsight sales. On completion of each project, infrastructure services and plots designated for public facilities were transferred either to the local authority (Gaborone City Council) or relevant central government agencies for operation, maintenance and/or further development. MLGLH provided primary and secondary infrastructure services only in two neighbourhoods-Blocks 6 and 7. The two neighbourhoods later became the first sites for attempts in implementing public private partnership in land servicing.

\subsection{Public-Private Partnership}

The foregoing discussion shows that the government introduced public-private partnerships in land servicing and housing delivery in Gaborone when it realised that it couldn't, on its own, meet the insurmountable demand for serviced plots and houses in urban areas. Two forms of partnerships appear to have been adopted with respect to land servicing in Gaborone: state-led and private sector led partnerships.

\subsubsection{State-Led Public-Private Partnerships}

In accordance with the 1994 directive, the government acquired several pieces of land in parts of Gaborone and provided primary infrastructure services such as arterial roads, trunk sewer lines and water mains. It allocated serviced blocks of land (up to 10 hectares) to private developers who demarcated the land into plots and provided secondary and tertiary services such as access roads, storm water drains and street lights. Allocation was done through the tender system on the basis of the reserve price. Developers were given the option to sell the serviced plots or to build houses for rental and/or selling. Each developer was given a 99 year lease for the entire block while plot and house buyers were given deeds of transfer covering the remainder of the principal lease period-often less than 99 years.

Between 1998 and 2001, about 20 private firms were allocated land for servicing and construction of houses and/or flats. The major beneficiaries are listed in Table 1. The largest private sector partner was Universal Builders followed a distant behind by Premier Projects, Diplomatic Services and Time Projects. As noted later, the 4 partners have been at the fore front of private sector led partnership.

In July 2000 Universal Builders applied for a 30 ha piece of land at an area called Maru a Pula. The area contained several burrow pits and disused refuse dump site. Universal Builders undertook to rehabilitate and service the area at its own cost. The company "pointed out that it needed the land to construct additional houses for sale to low income earners which it considered to be in the 
Table 1. Land allocated to private sector for servicing and development (1998-2001) ${ }^{3}$.

\begin{tabular}{cccc}
\hline No. & Company & $\begin{array}{c}\text { Amount of land } \\
\text { allocated in ha }\end{array}$ & $\begin{array}{c}\text { Planned number } \\
\text { of plots }\end{array}$ \\
\hline 1 & Universal Builder & 22.6 & 391 \\
2 & Premier Projects & 9.6 & 214 \\
3 & Diplomatic Services & 7.5 & 72 \\
4 & Time Projects (Botswana) & 7.2 & 118 \\
5 & Botswana Teachers Union & 5.6 & 64 \\
6 & Property Development and & 4.6 & 108 \\
7 & Valuation Surveyors & 4.9 & 115 \\
8 & Tswana Design Architects & 3.8 & 61 \\
9 & Mhango Building Construction & 3.0 & 48 \\
& Zimmal Reliance & 68.8 & 1191 \\
\hline
\end{tabular}

Source: Ministry of land and housing, 2001.

interest of the nation" (Government of Botswana, 2004: p. 123). The company was allocated the 30 ha piece of land at a price of P1 million (about P3.30 per $\mathrm{m}^{2}$ ) because it had argued that the cost of rehabilitating the burrow pits up to ground level would add up to P4 millions. Similar to other partnership projects, only high cost flats and medium cost houses have been erected on the reclaimed site.

All partners decided to build flats and houses for selling and renting. The houses were sold to "whosoever could purchase including non-citizens... [and didn't] accommodate the low income group" (Ministry of Lands and Housing, 2014: p. 5). The major challenge that surfaced relates to operation and maintenance of infrastructure services such as roads, sewerage, street lights and storm water drains. While the local authority (that is, Gaborone City Council) argued that land serviced by the private firms constituted "private estates", the private developers believed the networks formed part of the city council infrastructure networks. The Council was not prepared to collect refuse from homesteads in these estates. However, after a long and protracted negotiation process, the networks were eventually transferred to the local authority for operation and maintenance.

The 2004 Judicial Commission of Inquiry into State Land Allocation identified various flaws in land servicing and development under privatisation and public-private partnerships (Government of Botswana, 2004). First, it noted that a number private sector firms were allocated land for recreational, civic or industrial development but later converted the land to residential, commercial or office use. Second, some firms (e.g. Zimmal Reliance) sold the allocated blocks of land without providing the required secondary and tertiary infrastructure services (Government of Botswana, 2004: p. 83). Third, although some private 
firms were allocated land for servicing and construction of low income houses, the firms erected houses and flats for medium and high income groups. Fourth, it appears a few firms obtained the land at low prices either on pretext that they were going to build low cost houses or in collusion with civil servants.

\subsubsection{Private Sector Led Land Servicing Partnership}

Since the early 1990s, a number of private sector firms have been involved in land servicing and housing delivery projects in Gaborone. The key include Phakalane Estate, Kgale View and Maruapula. Phakalane Estate is by far the largest project and is worth discussing as a representative of private sector led partnership project.

1) Phakalane Estate

The Government approved conversion of the freehold farm known as Phakalane Estate from agricultural land use into a Township Development in November 1984. The approval followed government's adoption of the diversification policy discussed earlier. It was anticipated that the conversion from agricultural uses to township would promote industrial and commercial developments and thereby contribute to the country's economic diversification initiatives. The development of a township was also viewed as a strategy for local economic empowerment.

According to Pino (2012), financing of land servicing activities were made possible through a partnership with the Botswana Development Corporation - a state owned company-in 1989. Phase 1 of land servicing activities started in 1989 and were completed in 1991 at a cost of P18 million. Most of the plots serviced under Phase 1 were sold to prospective home owners although a few were sold to the Botswana Housing Corporation while some were developed by the Botswana Development Corporation. Phakalane Estate which is a private entity did not build houses for sale or rental although they constructed hotels, warehouses and commercial buildings.

Phakalane Estate encountered strong resistance when it tried to handover secondary and tertiary infrastructure services to the local authority-Gaborone City Council (GCC) - and respective utility parastatal companies-notably Botswana Power Corporation (BPC), and Water Utilities Corporation (WUC). First, GCC was reluctant to take over roads, street lighting, storm water and refuse collection, because it had not budgeted for them. Second, both BPC and WUC argued that connections to Phakalane Estate developments would increase pressure on existing infrastructure. They wanted Phakalane Estate, as the developer, to pay for the necessary improvements on the infrastructure. Third, WUC was not satisfied with the quality of infrastructure services being offloaded to them. According to Moeti (2012) and Gaotlhobogwe (2011) WUC demanded to be paid P30 million (USD 3.75 million as of 2012) being the cost of upgrading water supply and sewer systems while BPC demanded P22 million (USD 2.75) for upgrading its power supply substation. 


\section{Discussion}

Projects undertaken under the state-led PPP banner have contributed largely in construction of secondary infrastructure networks (access roads, water supply, drainage and storm water systems) and supply of houses. Their contribution has reduced housing shortages and saved public funds. The Government has made substantial financial savings with regard to provision of infrastructure services. As observed by Pino (2012) Phakalane Estate project has also generated numerous benefits. The most outstanding contribution made by private sector led PPP projects (such as Phakalane Estate) is the release of private (freehold) land for public use at no cost to the state or government. This is contrary to earlier practices where the government was forced to purchase freehold farms to facilitate expansion of cities and towns. The release of agricultural freehold land for housing, industrial, commercial and community facilities has reduced pressure on Gaborone City Council and filled the gap that the government could not. Secondly, the project has enabled the government to save money that it would spent on acquiring land and providing infrastructure facilities such as roads, water, electricity and storm water drainage. Third, the development of Phakalane Estate has contributed to government revenues-directly through property taxes and indirectly through the promotion of tourism, hotel and hospitality industries. Fourth, the growth of Phakalane Estate has created numerous construction, management, administrative and professional jobs at various stages of its evolution. Fifth, the township has had tremendous multiplier effects on local and national economies.

The adoption and application of the Public-Private Partnership concept in Botswana has been by default rather than by design. The launching of projects now classified under the PPP banner appear to have been driven by economic diversification and privatisation policies rather than the need to share risks and/or achieve efficiency. There were neither clearly defined responsibilities, expectations nor agreements on how to obtain finance, supply land, provide infrastructure networks, construct community, operate and maintain PPP projects. Worse still, local authorities and utility companies were neither consulted nor engaged in the design and implementation. This challenge was most prominent in private sector led projects. Consequently, local authorities and utility firms were not ready to takeover roads, street lights, refuse collection and other services developed under the banner of public private partnership because they didn't plan, budget nor prepare for them.

The projects were implemented without written agreements or legally binding instruments. Consequently, private partners pursued processes that would maximise their revenues and profits. All projects benefitted the elite, rich and, at most, middle income earners. The poor and other vulnerable groups were left out. Even schemes targeting the poor ended benefiting middle and high income earners. The poor have, as a result, been forced to find accommodation in peri-urban villages or reside in heavily congested but inadequately serviced 
self-help housing areas (Kalabamu \& Morolong, 2004).

The latest policy titled Strategy on Private Sector Participation in Land Servicing is also deeply flawed. It lays strong emphasis on government acquiring land either through willing-seller-willing-buyer arrangements or through compulsory acquisition. The undertaking whereby the government acquires land at market prices, provides peripheral infrastructure services and then resells it to private sector partners is an uncalled for bureaucratic process. The process is also liable to abuse and corruption. The proposed position of Accounting Officer/team consisting of representatives from over a dozen ministries, departments, utility providers and local authorities will introduce another layer in the land and housing delivery process.

\section{Conclusion and Way Forward}

Public Private Partnerships are a tool for reducing risks and operational costs as well as promoting efficiency and timely delivery of goods and services. The current practice is however not delivering all the potential benefits. To benefit from untapped opportunities inherent in public private partnership arrangements in land servicing, we recommend the following measures:

1) All public-private partnership projects should be guided by contracts, specific agreements or memorandum of understanding (MOU) between the government or the relevant state agency and the private firm. The contract should contain binding clauses on duties and responsibilities of all participating partners and delivery timelines.

2) The governments should give resources to equip agencies established to co-ordinate PPPs in the country so that the respective agencies are able to promote and support local authorities and state service departments to partner with the private sector instead of hiring or simply using them as consultants.

3) Negotiations on duties and responsibilities for each project should be inclusive of all potential partners-local authority, affected communities, service providers, land owners and so on. Participation of interested partners should start as early as the conception and design stages.

4) Freehold land owners and/or communal land rights holders should be facilitated to service their land for urban development in partnership with the private sector. The government should provide logistical support and funds for land servicing instead of the current double costs of purchasing and servicing the land. Participating partners should also agree on the value of land to be serviced, estimated costs, functions and duties to be undertaken by each party and how serviced plots or revenues from plot sales are to be shared.

The Government of Botswana has moved away from being the sole player in land servicing and housing supply in urban areas to being a facilitator and enabler. While the Government acknowledges the role of the private sector in land supply and servicing, it has not fully embraced the concept of public-private partnership. The Government wants to supply the land, provide bulk and pri- 
mary services and then partner with the private sector at the tail end of entire process. This major-minor partnership makes the Government the dominant player but denies it the full benefits of public private sector partnership. In addition, the Government has not adequately supported private sector initiatives in land servicing. Going forward, the Government needs to adopt a bottom-up approach by facilitating and supporting public-private partnerships between land owners and local authorities. Consultations for partnerships should start at grassroots level and involve all stakeholders' right from the conception to the implementation and transfer stages.

\section{References}

Abdul-Aziz, A. R., \& Kassim, P. S. J. (2011). Objectives, Success and Failure Factors of Housing Public-Private Partnerships in Malaysia. Habitat International, 30, 448-461. https://doi.org/10.1016/j.habitatint.2010.06.005

Adusumilli, U. (1999). Partnership Approaches in India. In G. Payne, (Eds.), Making Common Ground: Public-Private Partnerships in Land for Housing (pp. 17-45). London: Intermediate Technology.

Ahmed, N. (1999). Public-Private Partnerships in Pakistan. In G. Payne, (Eds.), Making Common Ground: Public-Private Partnerships in Land for Housing (pp. 17-45). London: Intermediate Technology.

Akintoye, A., Beck, M., \& Hardcastle, C. (Eds.) (2003). Public-Private Partnerships: Managing Risks and Opportunities. Oxford: Blackwell.

Asian Development Bank (ADB) (2009). ADB Assistance for Public-Private Partnerships in Infrastructure Development-Potential for Success. Manila: ADB.

Clifton, C. W., \& Roscoe, D. A. (1984). An Assessment of Housing Needs, Affordability and Potential Barriers to Successful Implementation. Washington DC: U.S. Agency for International Development (USAID). https://doi.org/10.1002/9780470690703

Colclough, C., \& McCarthy, S. (1980). The Political Economy of Botswana: A Study of Growth and distribution. Oxford: Oxford University Press.

Commission of the European Community (CEC) (2005). Report on the Public Consultation on the Green Paper on Public-Private Partnerships and Community Law on Public Contracts and Concessions. Brussels: CEC.

Dickson, W. L. (1990). Land Tenure and Management in a Developing Country. NIR, University of Botswana, Working Paper No. 54.

Envirometrix (2017). Serowe Planning Area Development Plan 2014-2038 (Draft). Serowe: Central District Council.

Euroconsult (1990). An Analysis of Providing Serviced Land and Housing in Botswana's Seven Urban Centres. Gaborone: Ministry of Local Government and Lands.

Gaotlhobogwe, M. (2011). Nothing Wrong with Phakalane Sewer System-Report. http://www.mmegi.bw

Government of Botswana (1983). An Evaluation of the Self-Help Housing Agencies. Gaborone: Ministry of Local Government and Lands.

Government of Botswana (1987). Report on the Proceedings of the National Conference on Housing. Gaborone: Ministry of Local Government and Lands.

Government of Botswana (1992). Report of the Presidential Commission of Inquiry into 
Land Problems in Mogoditshane and Other Peri-Urban Villages. Gaborone: Government Printers.

Government of Botswana (2003). National Development Plan 9: 2003/4-2008/9. Gaborone: Ministry of Finance and Development Planning.

Government of Botswana (2004). Report of the Judicial Commission of Inquiry into State Land Allocation in Gaborone. Gaborone: Government Printer.

Government of Botswana (2009a). National Development Plan 10: 2009/10-2014/15. Gaborone, Ministry of Finance and Development Planning.

Government of Botswana (2009b). Public-Private Partnership Policy and Implementation Framework. Gaborone: Government Printers.

Hawkesworth, I. (2011). From Lessons to Principles for the use of Public-Private Partnerships. Luxemburg: OECD.

Jones, G. A., \& Pisa, R. A. (2000). Public-Private Partnerships for Urban Development in Mexico: A Victory for Hope versus Expectation? Habitat International, 24, 1-18.

Kalabamu, F. T. (1993). An Appraisal of Botswana's Accelerated Urban Land Servicing and Housing Programme. Botswana Journal of Technology, 1, 30-38.

Kalabamu, F. T. (2000). Land Tenure and Management Reforms in East and Southern Africa-The Case of Botswana. Land Use Policy, 17, 305-319. https://doi.org/10.1016/S0264-8377(00)00037-5

Kalabamu, F. T., \& Morolong, S. (2004). Informal Land Delivery Processes and Access to Land for the Poor in Greater Gaborone. Working Paper No. 3, University of Birmingham.

Kasala, S. E., \& Burra, M. M. (2016). The Role of Public Private Partnerships in Planned and Serviced Land Delivery in Tanzania. iBusiness, 8, 10-17.

Letsholo, J. M. O. (1990). The Role of Botswana Housing Corporation-Possible Future Scenarios. In 2 nd National Housing Conference.

Ministry of Lands and Housing (2014). Strategy on Private Sector Participation in Land Servicing. Republic of Botswana.

Moeti, M. (2012). Are Dark Forces at Play Phakalane. Sunday Standard. http://www.sundaystandard.info

Molebatsi, C. O. (1990). A Review of Botswana's National Housing Policy-Towards a Meaningful Support Policy for Housing Provision. In 2nd National Housing Conference.

Mosha, A. C. (2005). Mobilizing Public Finance for City Development and Management in African Countries. In Africa Regional Seminar on Enhancing Resource Allocation to Cities for Strengthening their Role as Engines of Economic Growth and Development.

Mpabanga, D. (2011). Public Sector Performance Measurement and Accountability in Botswana. In D. Greiling, A. Halachmi, \& R. Schauer, (Eds.), Accounting, Accountability and Governance in Public Sector: 9th International Symposium on Public Sector Management (pp. 149-172). Linz: Johannes Kepler University.

Payne, G. (1999). Making Common Ground: Public-Private Partnerships in Land for Housing. London: Intermediate Technology.

Pino, J. (2012). Building Lasting Success Phakalane: The Sandton of Botswana. Gaborone: Pino Press.

Scribner, M. (2011). The Limitations of Public-Private Partnerships: Recent Lessons from Surface Transportation and Real Estate Sectors. Washington DC: Competitive Enter- 
prise Institute.

Sengupta, U. (2006). Government Intervention and Public-Sector Partnership in Housing Delivery in Kolkata. Habitat International, 30, 448-461. https://doi.org/10.1016/j.habitatint.2004.12.002

Silitshena, R. M. K. (1984). Urbanisation in Botswana. Nordic Geographical Journal, 38, 109-128.

UN Habitat (2011). Public-Private Partnerships in Housing and Urban Development. Nairobi: United Nations Human Settlements Programme. 